\title{
Life-course influences on social inequality in adult mortality risk: A review
}

\author{
Øyvind Næss and Bjørgulf Claussen \\ Institute of General Practice and Community Medicine, University of Oslo, Norway \\ Correspondence to: Ø. Næss, Institute of General Practice and Community Medicine, P.O. Box 1130 Blindern, N-0317 Oslo, Norway \\ Telephone +4722850606 Telefax +4722850610 E-mail: oyvind.nass@samfunnsmed.uio.no
}

\begin{abstract}
NORSK SAMMENDRAG
I senere års forskning om sosiale ulikheter og helse har livsløpet som modell fått økt oppmerksomhet. I denne modellen oppfattes risiko for sykdom og død som et resultat av oppsamlet sosialt og biologisk mediert risiko gjennom et livsløp. Modellen kan ses på som et kompromiss mellom og videreføring av, den multifaktorielle årsaksmodellen (risikofaktorer i voksen alder) og programmeringshypotesen (risiko for kroniske sykdommer determineres i svangerskap eller i tidlig barndom). Denne artikkelen gjennomgår arbeider hvor sosialt og biologisk mediert risiko for ulike dødsårsaker gjennom et livsløp er studert.
\end{abstract}

\section{INTRODUCTION}

Life-course and health have been in focus of research for the last decade. This has developed jointly with a revival of interest in social inequality in health. The prevailing model in chronic disease epidemiology of multiple causation and risk factors has been challenged in recent years with a growing interest in long-term determinants of chronic diseases. This is historically not new; in early 20 th century public health there was a lot of interest in growth and the influence of the young generation's health on future trends (1). However, the focused and massive efforts in contemporary research has made some commentators call it a shift in paradigm $(2,3)$. Also, the lifelong focus has been seen as a fruitful perspective in explaining social inequality in health. Longitudinal designs have enabled researchers to study socioeconomic influences from different stages of the life-course, and also to look at how this manifests in different diseases.

In this paper we want to review the evidence on socioeconomic life-course influences on adult mortality risk. This evidence we want to present for the most common causes of death in developed countries. Some of the proposed mechanisms will be discussed in the light of possible biological and social pathways.

\section{EXPLAINING HEALTH INEQUALITIES}

Traditionally, most research in health inequality has focused on general explanations such as material circumstances, health-related social selection and behavioural/cultural patterns $(4,5)$. Far less attention has been given to cause-specific inequalities and their distribution. In some of the earlier publications, a general susceptibility was suggested to underlie the inequality in health $(6,7)$. This way of reasoning is concordant with psychosocial stress as a unifying mechanism of health inequalities. On the other hand, this notion of a general principle has been challenged by some. Heterogeneity in gradient between specific causes has been shown (8). This has been particularly demonstrated with specific cancer sites where some of them are more prevalent in higher socioeconomic groups $(9,10)$. Additionally, as The Black Report pointed out, a distinction is necessary between the fundamental and proximal causes of socioeconomic inequality in health (11). Smoking is in this regard an intermediate or proximal cause whereas the socioeconomic structuring of smoking behavior would be seen as a fundamental one. And with this distinction in mind, the patterning of risk along the life-course will differ between causes of death.

\section{SOME CAUSE-SPECIFIC INEQUALITIES}

Within the broad category of cardiovascular diseases, coronary heart disease and stroke seem to differ in their respective trends of mortality during the 20th century even though their adult risk factors are to some degree similar $(12,13)$. Coronary heart disease mortality followed a bell-shaped curve with an increase until the 1970s and a subsequent decline from then. Stroke mortality fell gradually during the whole century. Several studies have found a stronger relative association between childhood factors in stroke mortality risk than in coronary heart disease mortality risk (14). This is consistent with trends where long-term improvements of childhood conditions have co-occurred with a decline in stroke mortality. The relationship between childhood socioeconomic conditions and coronary heart disease was originally demonstrated by Forsdahl and Barker $(15,16)$. Their work has spurred intensive research into the in utero and childhood programming of a lot of other adult chronic diseases. Coronary heart disease is associated with a myriad of risk factors most of which are socially patterned (18). They are distri- 
buted over the life-course. The disease has a long incubation time so it stands out as one of the most typical diseases whose determinants should be sought across the entire life course (19).

Cancers generally show a heterogeneous pattern according to which cancer site is concerned. Socioeconomic differentials in cancer mortality can arise as a consequence of inequality in access to preventive and treatment services or inequality in incidence. The latter is more of interest here. For smoking-related cancers, the direction of the gradient is largely dependent on the socioeconomic distribution of smoking in a particular population (8).

For the non-smoking related cancers, the most consistent pattern is shown for breast cancer and stomach cancer. Breast cancer is associated with improving and stomach cancer with worsening social circumstances. Few studies have compared early and later factors in other cancers. In anthropometric studies the association between height in childhood or adulthood and later risk of non-smoking related cancer shows a rather consistent pattern of increased risk with height (2023). Although height is highly genetically determined, to some extent it could be a marker of childhood social circumstances. Later life risk factors include diet, alcohol consumption, exposures to some infections and occupation, which are thought to be socially determined. In migrant studies, women migrating out of their area of birth take with them risk of breast cancer, which indicates importance of early life factors $(24,25)$. Many of the known risk factors for the disease such as parity and age of first birth are socially mediated.

Stomach cancer has in recent years been linked to infection with helicobacter pylori $(26,27)$. Its association with low socioeconomic conditions is seen in various populations $(9,28)$. In trend studies, the disease has dramatically declined over several decades. And when cohort effects have been studied, causative factors in early childhood have been suggested (29). As helicobacter pylori infection mainly occurs in childhood with poor sanitary and socioeconomic circumstances, it could have an important role in the secular change in stomach mortality.

Respiratory related deaths, including chronic obstructive lung disease (COPD), show marked socioeconomic gradients. But also, an effect on respiratory function has been shown to be over and above what could be accounted for by smoking, and even for lung cancer mortality this has been suggested (30). A socioeconomic gradient on bronchitis mortality has been demonstrated before smoking was socially patterned (31). Bronchitis mortality has been linked with birth weight, childhood infections and poor nutrition (3235). Also, in several studies, respiratory mortality has been linked to childhood social conditions after controlling for adulthood social factors. In terms of life course influences on violent and suicidal causes of death, they have not been much studied, and will not be reviewed here.

\section{SOCIAL AND BIOLOGICAL MECHANISMS}

Modelling disease risk with such a strong emphasis on the full life-course makes a simple mechanistic view on disease causation problematic. Social and biological factors are seen to contribute mutually in pathways of various diseases. Before World War II, there was an urgent interest in elucidating the causes of lower respiratory illness in working men in Britain, and the effect of pollution was acknowledged. Later, Reid and Barker took a longer perspective and concluded that the risk of chronic obstructive pulmonary disease was established early in life by tracking respiratory function and childhood respiratory illness from childhood and/or by the effect of the intrauterine environment on subsequent risk (36). Barker has extended this hypothesis in a number of other publications on other diseases such as coronary heart disease and glucose intolerance. In Norway, Forsdahl proposed early a hypothesis of biological programming in his studies of living conditions in childhood, affluence in later life and risk of coronary heart disease. The model of intrauterine programming has triggered an exponential growth in research, and today the prospect of further development has been suggested to lie in basic animal and laboratory research (37).

Socioeconomic circumstances is a collective term of a wide range of factors that may influence health, such as educational attainment from early life, occupational status, household circumstances and income throughout life. Although their relative influence on mortality risk is little studied, they are thought to be associated differently in various mortality outcomes (38-40). Poverty, unemployment, poor home circumstances, and parental education are associated with many aspects of health in early life, which may raise adult disease risk. These include poor prenatal and postnatal growth, respiratory infection, and poor maternal and child nutrition. Later, poor housing, educational attainment and growth are important factors. Childhood growth is associated with health status in childhood. And health status in childhood is an important determinant of future educational attainment. Also, exposure to an environment of risk-taking behaviour is involved in determining the establishment of smoking, exercise, nutrition and other aspects of lifestyle in adolescence (41).

Thus, the model of risk that is proposed in this framework is one of biological chains of risk and one of social chains of risk (36). Depicting the natural history of disease demands an exhaustive account of these two chains. COPD is a good example because extending the framework of this disease in a life-course perspective can also provide the steps needed in developing powerful strategies of prevention. Early in life, living in crowded conditions, having poor housing and air quality, financial constraints, and parental behaviour may adversely affect nutrition during pregnancy. And frequent respiratory infections during childhood 
can damage or restrict lung development and growth. During adolescence, parents, peers and educational experience influence the uptake of cigarette smoking. In adulthood, cultural influences, exposures to stress, and individual characteristics affect the chance of giving up smoking, and the type of occupation affects exposure to fumes and dust. In later life the progressive loss of respiratory function eventually limits physically demanding jobs such as manual ones, giving earlier symptoms. Subsequent pension will then reduce living standard. In contrast with the processes suggested by the biological programming hypothesis, the social hypothesis are not suggested to operate mainly at critical developmental periods. Rather, the social factors are thought to operate in a cumulative fashion.

\section{THE DIMENSION OF TIME AND COHORT}

Ben-Shlomo, Davey Smith and other researchers have looked at the relative contribution of childhood and adulthood social circumstances on adult mortality risk, and found a tendency towards stronger influence being set in childhood (8). As was discussed in the previous section, this relative influence is probably variable in various diseases. These striking findings have their parallels in historical studies of vital statistics and mortality trends of birth and period cohorts. They seem to indicate that as time has unfolded, the generations that were born into new cohorts bring into their adult lives vulnerability patterned by the predominant context of biological and social risk of their time (31). Smoking provides one example. Those born in a time of low rates of maternal smoking will not be exposed to that effect from their early years, but the take-up of the smoking habit in the time when these women are adults may encourage them to start at a later stage. Likewise, the availability of medical care and periodic epidemics change in historical time (36). The time dimension poses an extra challenge for the study of lifecourse influences because their importance varies in time. This means the determinants of social inequality in mortality risk varies over time for various causes.

\section{SOME METHODOLOGICAL CHALLENGES}

One problem of studying life-course influences on adult mortality risk is that it is difficult to disentangle their relative influence because of interdependence between social circumstances in early and later life, and between social and biological factors. This means that independent effects will be difficult to estimate. Adult mortality of obstructive bronchitis can certainly be associated with childhood infections, but morbidity in childhood is likely to cause school absence, reduced educational attainment, which eventually may trigger initiation of smoking. The possibility of a cumulative, independent and/or interaction effect of each life-stage will be better to study once the many birth cohorts have reached mature age. Similarly, risk factors for coronary heart disease are associated with living conditions in childhood and socioeconomic status. When these are adjusted for, and the association between socioeconomic status and mortality risk becomes attenuated, it is still difficult to know to what degree the association is mediated via these risk factors, and how much is independent of them. Both the outcome and possible mediating factors are associated and clustered within low socioeconomic groups and poor childhood living conditions, so when they are adjusted for, it will be difficult to explain what could be the ultimate cause (18). Other authors have questioned the validity of the programming hypothesis on similar ground (3). Low birth weight as a marker of the intra-uterine environment could largely be explained as socioeconomic or genetic confounding. And leg length in childhood as a cause of adult mortality risk could easily be explained by selection of long-legged individuals into higher socioeconomic conditions.

\section{Conclusion}

Life-course as a model of explaining mortality patterns and social inequality provides a new framework of analysis and further research. In itself it does not seem to be a particular hypothesis as such. Rather, it appears as an extension of the multiple causation model, that was predominant in post World War II epidemiology because this model failed to explain residual risk beyond the adult risk factors (42). In addition, it provides a lengthy wanted tool of explaining social inequality in mortality in more detail by looking at particular causes of death. Some evidence of life-course influences on particular causes of death has been reviewed. However, there are strong analytical challenges in studying the independence of effects along the life-course.

\section{REFERENCES}

1. Kuh D. When is mortality risk determined? Historical insights into a current debate. Soc Hist Med 1993; 6: 101-23.

2. Susser M. Foreword. In: Ben-Shlomo Y, ed. A life course approach to chronic disease epidemiology. Oxford: Oxford University Press, 1997.

3. Susser M, Levin B. Ordeals for the fetal programming hypothesis. BMJ 1999; 318: 885-6. 
4. Davey Smith G, Blane D, Bartley M. Explanations for socio-economic differentials in mortality: evidence from Britain and elsewhere. Eur J Public Health 1994; 4: 131-44.

5. Macintyre S. The Black Report and beyond: what are the issues? Soc Sci Med 1997; 44: 723-45.

6. Marmot MG. Inequalities in death - specific explanations of a general pattern? Lancet 1984; i: 1003-6.

7. Najman JM. Theories of disease causation and the concept of a general susceptibility: a review. Soc Sci Med 1980; 14A: 231-7.

8. Ben-Shlomo Y, Davey Smith G. Deprivation in infancy or in adult life: which is more important for mortality risk? Lancet 1991; 337: 530-4.

9. Faggiano F, Partanen T, Kogevinas M, Bofetta P. Socioeconomic differences in cancer incidence and mortality. In: Boffeta P, ed. Social Inequalities in Cancer. Lyon: IARC Scientific Publications no. 138, 1997: 65176.

10. Davey Smith G, Leon D, Shipley MJ, Rose G. Socioeconomic differentials in cancer among men. Int $J$ Epidemiol 1991; 20: 339-45.

11. Black D, Whitehead M, Townsend P. Inequalities in health. Harmondsworth: Penguin Books, 1988.

12. Beaglehole R. International trends in coronary heart disease mortality and incidence rates. J Cardiovasc Risk 1999; 6: 63-8.

13. Thom TJ, Epstein FH. Heart disease, cancer, and stroke mortality trends and their interrelations. An international perspective. Circulation 1994; 90: 574-82.

14. Davey Smith G, Hart C, Blane D, Hole D. Adverse social circumstances and cause-specific mortality: prospective observational study. BMJ 1998; 316: 1631-5.

15. Forsdahl A. Living conditions in childhood and subsequent development of risk factors for arteriosclerotic heart disease. The cardiovascular survey in Finnmark 1974-75. J Epidemiol Community Health 1978; 32: $34-$ 7.

16. Forsdahl A. Are poor living conditions in childhood and adolescence an important risk factor for arteriosclerotic heart disease? Br J Prevent Soc Med 1977; 31: 91-5.

17. Barker DJP. Mothers, babies and health in later life. Edinburgh: Churchill Livingstone, 1998.

18. Davey Smith G, Gunnel D, Ben-Shlomo Y. Life-course approaches to socio-economic differentials in causespecific adult mortality. In: Leon D, ed. Poverty, inequality and health. Oxford: Oxford University Press, 2000.

19. Rose G. Incubation period of coronary heart disease. BMJ 1982; 284: 1600-1.

20. Gunnell DJ. Leg length and risk of cancer in the Boyd Orr cohort. BMJ 1998; 317: 1350-1.

21. Albanes D, Jones DY, Schatzkin A, Micozzi MS, Taylor PR. Adult stature and risk of cancer. Cancer Res 1988; 48: 1658-62.

22. Leon DA, Davey Smith G, Shipley M, Strachan D. Adult height and mortality in London: early life, socioeconomic confounding, or shrinkage? J Epidemiol Community Health 1995; 49: 5-9.

23. Hebert PR, Ajani U, Cook NR, Lee IM, Chan KS, Hennekens CH. Adult height and incidence of cancer in male physicians (United States). Cancer Causes Control 1997; 8: 591-7.

24. Buell P. Changing incidence of breast cancer in Japanese-American women. J Natl Cancer Inst 1973; 51: 1479-83.

25. Barbone F. Socioeconomic status, migration and the risk of breast cancer in Italy. Int J Epidemiol 1996; 25: 479-87.

26. Forman D. Association between infection with Helicobacter pylori and risk of gastric cancer: evidence from a prospective investigation. BMJ 1991; 302: 1302-5.

27. Parsonnet J. Microbes and malignancy: infection as a cause of human cancers. Oxford: Oxford University Press, 1999.

28. Brown LM. Helicobacter pylori: epidemiology and routes of transmission. Epidemiol Rev 2000; 22: 283-97.

29. Hansson LE. The decline in the incidence of stomach cancer in Sweden 1960-1984: a birth cohort phenomenon. Int J Cancer 1991; 47: 499-503.

30. Martikainen P. Educational differences in lung cancer mortality in male smokers. Int J Epidemiol 2001; 30: 264-7.

31. Stratchan D. Respiratory and allergic diseases. In: Ben-Shlomo Y, ed. A life course approach to chronic disease epidemiology. Oxford: Oxford University Press, 1997: 15-41.

32. Shaheen S. The beginnings of chronic airflow obstruction. Br Med Bull 1997; 53: 58-70.

33. Shaheen SO. Birth weight, childhood lower respiratory tract infection, and adult lung function. Thorax 1998; 53: 549-53.

34. Shaheen SO. The relationship between pneumonia in early childhood and impaired lung function in late adult life. Am J Respir Crit Care Med 1994; 149: 616-9. 
35. Barker DJ, Godfrey KM, Fall C, Osmond C, Winter PD, Shaheen SO. Relation of birth weight and childhood respiratory infection to adult lung function and death from chronic obstructive airways disease. BMJ 1991; 303: 671-5.

36. Wadsworth ME. Health inequalities in the life course perspective. Soc Sci Med 1997; 44: 859-69.

37. Davey Smith G, Ebrahim S. Epidemiology - is it time to call it a day? Int J Epidemiol 2001; 30: 1-11.

38. Davey Smith G, Hart C, Hole D, et al. Education and occupational social class: which is the more important indicator of mortality risk? J Epidemiol Community Health 1998; 52: 153-60.

39. Sorlie PD. US mortality by economic, demographic, and social characteristics: the National Longitudinal Mortality Study. Am J Public Health 1995; 85: 949-56.

40. Sundquist J, Johansson SE. Indicators of socio-economic position and their relation to mortality in Sweden. Soc Sci Med 1997; 45: 1757-66.

41. Kuh D, Ben-Shlomo Y. A life course approach to chronic disease epidemiology. Oxford: Oxford University Press, 1997.

42. Kuhn TS. The structure of scientific revolutions. Chicago: University of Chicago Press, 1962. 